This item was submitted to Loughborough's Research Repository by the author.

Items in Figshare are protected by copyright, with all rights reserved, unless otherwise indicated.

\title{
Future opportunities for offsite in the UK
}

PLEASE CITE THE PUBLISHED VERSION

PUBLISHER

(C) Taylor \& Francis

LICENCE

CC BY-NC-ND 4.0

REPOSITORY RECORD

Goodier, Chris I., and Alistair G.F. Gibb. 2019. "Future Opportunities for Offsite in the UK". figshare. https://hdl.handle.net/2134/3100. 
This item was submitted to Loughborough's Institutional Repository by the author and is made available under the following Creative Commons Licence conditions.

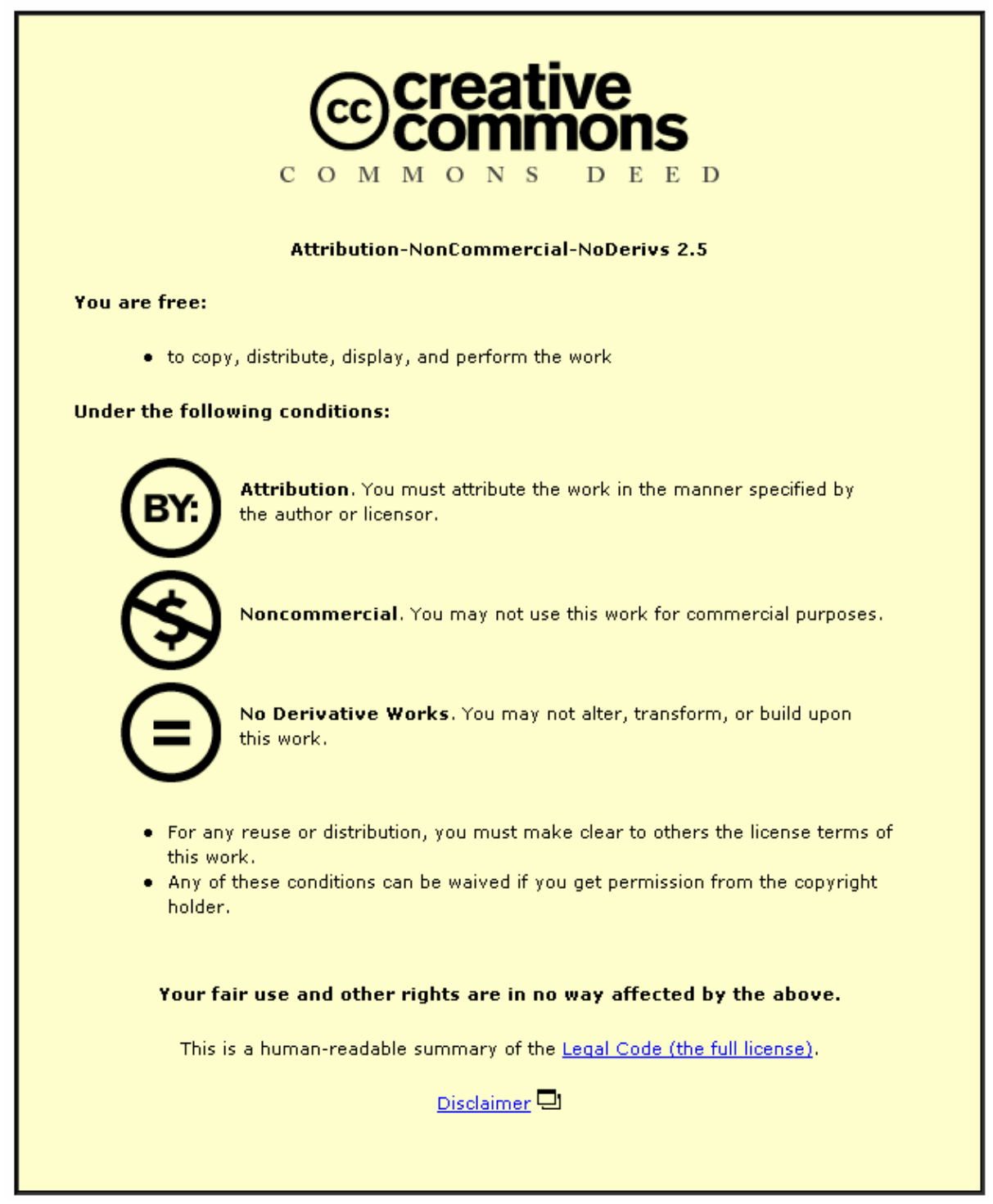

For the full text of this licence, please go to: http://creativecommons.org/licenses/by-nc-nd/2.5/ 


\section{Future opportunities for offsite in the UK}

Goodier, C.I. \& Gibb, A.G.F.

\section{Abstract}

Practitioners views and opinions on the benefits and drawbacks of offsite technologies in the UK construction industry can vary widely, often depending upon their role or position. This research provides an indication of the opinions of the different sectors within the industry, including clients, designers, contractors, and offsite suppliers, together with some predictions for the future growth of the offsite sector in the UK. A questionnaire survey of UK construction was conducted in order to target the three main construction industry sectors - suppliers/manufacturers, contractors and designers/clients. More than 80 questionnaires were completed and returned. The vast majority of practitioners within the industry are aware of the possibilities and potential of offsite, and most also understand the advantages and disadvantages of its use. The value of the UK offsite market was valued at $£ 2.2 \mathrm{bn}$ in 2004 and the demand for offsite is clearly increasing, but it is not always clear in a project who is the main driver for its use. For the offsite market to develop further however, two main problems need to be addressed; the lack of transparent information for the decision makers in the construction process, particularly that relating to comparative costs, and the lack of available multi-skilled labour to work in the offsite factories.

Keywords: Future studies, Off-site production, Prefabrication, Standardization 


\section{Introduction}

Industry advisors and experts frequently inform the construction industry that they should use more offsite and standardisation in order to increase quality and reduce cost and time; indeed, much recent work reporting on the future of the construction industry see offsite as one of the key issues of the future (Harty et al, 2006, Soetanto et al, 2006 and Pan et al, 2006).

Despite increasing interest in the use of offsite, the UK remains behind similar economies in the take-up of offsite and other forms of modern methods of construction (MMC). Two factors drive this growing interest. First, an increased demand for housing, particularly in the SE and particularly for lowoccupancy dwellings. Housing supply in the UK has fallen to its lowest level since WW2 and output in 1993-2002 was 12\% lower than for the previous 10 years (Barker, 2004). This shortfall in housing supply is constraining economic growth, restricting access to housing and affecting the distribution of wealth within our society. Similar studies have shown that 225,000 new homes will be needed each year up to 2016 in England alone, with the majority of this demand expected to be in Southern England, with 20\% concentrated in London (Barlow et al. 2002). It does not help current offsite suppliers and manufacturers that some types of offsite are historically associated with poor quality housing and social exclusion (Goodier and Gibb, 2005a, Pan et al, 2006). If this association recurs, then there will be a risk of it becoming socially unacceptable, leading to it being viewed as a failure. 
Second, there is increasing pressure from Government to emulate the manufacturing sector, despite its difference to construction. For example, Egan (1998) identified targets for improvement in construction productivity and profits, as well as in defect and accident reduction. These combined pressures combine with the industry's own interest in improving performance to encourage rising interest in MMC, including offsite.

Loughborough University recently took part in a DTI-funded research programme called $\mathrm{prOSPa}^{1}$ which aimed to realise the potential of offsite and thus improve the performance of the UK construction industry (Goodier and Gibb, 2004). This initiative has now been replaced by Buildoffsite ${ }^{2}$ which aims to further develop and promote offsite applications in the UK construction sector. PrOSPa aimed to investigate the views of the UK construction industry on offsite. An indication of the opinions of the different sectors within the industry is outlined here, together with the results from several other recent reports on offsite in order to form a cogent report on offsite in the UK. The types of organisation which participated in the main prOSPa survey are shown in Table 1.

For this research, offsite is defined as the manufacture and pre-assembly of components, elements or modules before installation into their final location.

${ }^{1}$ prOSPa, or promoting OffSite Production applications, was a consortium composed of Co-Construct members (BSRIA, CIRIA, The Concrete Society, $\mathrm{SCl}$ - The Steel Construction Institute and TRADA Technology) and Loughborough University and was funded by DTI.

${ }^{2}$ www.BuildOffsite.com 
Other terms in use for offsite include Offsite Production (OSP), Offsite Fabrication (OSF), Offsite Manufacturing (OSM), Offsite Construction (OSC), pre-assembly and prefabrication. Whereas most offsite may be considered to be MMC, not all MMC can be regarded as offsite.

MMC is a term introduced by the ODPM ${ }^{3}$, initially as a link to grant funding for Social Housing. The great majority of MMC techniques are covered by the offsite definition described above, although there are a few onsite MMC techniques such as thin-jointed blockwork, insulated (polystyrene) formwork, brick slips and tunnel form concrete applied to residential developments. Offsite can be categorised into 4 levels generally associated with the degree of offsite work undertaken on the product (Gibb, 1999). Respondents were asked, where possible, to try and orientate their replies to these 4 levels (Table 2).

\section{Survey method}

The data for this report was obtained from four main sources within the prOSPa project (Goodier and Gibb, 2004):

1. a literature review of existing recent surveys and publications on offsite;

2. a preliminary survey of six organisations to assist in finalising the focus for the main survey;

3. a main questionnaire survey of 75 UK construction organisations, including 39 clients and designers, 13 contractors and 23 offsite suppliers and manufacturers;

${ }^{3}$ ODPM- Office of the Deputy Prime Minister (UK) 
4. a prOSPa Programme Steering Committee workshop on the $6^{\text {th }}$ July, 2004, with 13 delegates from organisations such as the CPA, British Precast Concrete Federation, Constructing Excellence, Housing Corporation, TRADA, BSRIA and SCI.

In addition, a survey of the size of the offsite market in the UK was conducted for Buildoffsite based upon several key survey reports on different sectors of the offsite industry (Goodier and Gibb, 2005b).

\section{Survey results}

Table 3 shows that the main areas of construction in which the respondents are involved were generally public/social and private housing, offices and hospitals/health. This activity reflects the rise in the proportion of offsite that is housing related, which has been estimated to rise from around $60 \%$ of total offsite production in the early years of this decade to about $73 \%$ in 2006 (Venables et al., 2004).

More than 9 out of 10 of the clients, designers and contractors in this study had used some form of offsite in at least one of their projects. Interestingly, one of the contractors was not sure if they had or not. Most types of offsite had been used by more than half of the respondents (Figure 1).

\section{Advantages, barriers and drivers}

The majority of the clients and designers (73\%) claimed that they were sufficiently aware of the relative advantages and disadvantages of offsite over 
traditional construction, compared with just over half (54\%) of the contractors surveyed. However, less than a third (30\%) of the suppliers questioned thought that their customers were aware of the relative advantages and disadvantages.

This difference in understanding of offsite is a frequent source of frustration for suppliers, with customers believing that they are aware of the relative advantages and disadvantages but suppliers knowing, or believing, that they are not. Some suppliers believe that there is an "extraordinary" lack of understanding in all sectors of the construction industry of the full benefits of offsite and that the general understanding of some practitioners means "volumetric modular boxes, usually grey". Many customers routinely use methods such as precast concrete without appreciating that this is a form of offsite. Conversely, some contractors complain that suppliers are not always fully aware of how tendering works in traditional construction, what the price means in contractual terms, and the importance of early notification if anything is changed in the design that will cause costs to rise. Improved education, communication and experience are all required to help bring these groups closer together.

The biggest advantage of offsite compared with traditional construction is thought to be the decreased construction time on site (Table 4). Unsurprisingly, this factor is of particular benefit to contractors, with 9 of the 13 questioned ranking this as their number 1 advantage. Increased quality was also highly ranked by all respondents. These two advantages have also 
come out top in previous offsite studies (Samuelsson Brown et al, 2003 and Venables et al, 2004). A more consistent product and reduced snagging and defects were also seen as advantages by the majority of respondents, although more so by the clients/designers than by contractors. Overall, more of the client/designers selected each of the possible advantages compared with the contractors, which reflects the similarly higher proportion of who said that they were aware of the potential advantages of offsite.

The belief that using offsite is more expensive than traditional construction is clearly the main barrier to the increased use of offsite in the UK (Table 5), even though a large proportion of the respondents contradictedly thought that one of the advantages of using offsite was both a reduced initial cost and a reduced whole life cost (Table 4). Decisions required to choose one method of construction over another involving offsite are also too often based on cost rather than value (Blismas et al, 2006 and Venables et al, 2004). Tools such as IMMPREST ${ }^{4}$ have sought to provide a framework for comparing and costing solutions in a holistic manner (Blismas et al, 2003). Notwithstanding, other advantages such as increased quality and reduced snagging are rarely included in costings and many projects are still judged purely on first or initial cost, either intentionally or unintentionally.

\footnotetext{
${ }^{4}$ IMMPREST (Interactive Method for Measuring PRE-assembly and STandardisation benefit in construction) by Loughborough University, wwW.IMMPREST.com).
} 
Many house buyers are so strongly influenced by negative perceptions of post-war 'pre-fab' that they will resist any innovations in house construction which affect what a 'traditional' house looks like, including offsite (RGU, 2002). This resistance to innovative house-building also resides within the industry itself, where commitment to innovation has not diffused throughout organisations sufficiently in order to bring it about.

Resistance to change and the poor or negative image of offsite are factors that are prominent in many recent surveys on offsite (Samuelsson Brown et al 2003, Venables et al, 2004 and RGU, 2002), with the resistance to change being indicative not just of offsite, but of many innovations within the UK construction industry.

Longer lead-in times were also identified as a significant barrier, especially to contractors, as the use of offsite could delay the beginning of the project on site. It was commented that offsite, "needs to be integrated from the start of the design process" in order to minimise lead-in times and that, "the whole design and construction process of offsite suppliers and contractors needs to be more aligned" in order to shorten the lead-in time and reduce costs.

Supply chain integration and education, and design flexibility were also the two main areas that suppliers thought needed the most attention: "Suppliers need to be working with the developers, architects and contractors at the earliest stage of a development to ensure that the appropriate offsite techniques can be integrated into the building design." 
Who usually drives the idea of using offsite for a particular project depends upon who you speak to, as can be seen in Figure 2. The majority of clients and designers think that it is the client who usually drives the use of offsite on a project, together with the contractor, designer and architect. Contractors however, feel that it is more themselves and the architect who are the drivers. Suppliers on the other hand, think they themselves are one of the main drivers. This shows that it is not just the suppliers who are driving for the increased use of offsite, but all sectors of the construction industry are at times, and on particular projects, driving for the use of offsite. The final decision whether to use offsite on a project is often left to the main contractor, architect and client in the non-M\&E areas and down to the M\&E contractor or consultant in M\&E applications (Samuelsson Brown et al, 2003) ${ }^{5}$.

\section{Demand for offsite}

Nearly three quarters of the suppliers surveyed thought that the take-up of offsite was increasing in their sector, with only one respondent thinking that it definitely was not.

Only two of the 23 suppliers in this survey thought that the demand for offsite levels 3 and 4 was currently being met by the UK supply side and around $40 \%$ thought that demand for offsite levels 1 and 2 was currently being met. This is

\footnotetext{
${ }^{5}$ The is due to the fact that much of the M\&E (Mechanical and Electrical) services in UK building projects are installed by dedicated sub-contractors.
} 
despite recent work showing that UK offsite suppliers for housing were currently working at only $70 \%$ of their maximum plant output, with a predicted increase to around $80 \%$ by 2006 (Venables et al, 2004).

The perceived negative image of offsite was the main factor that suppliers thought was limiting their ability to expand to this 'increasing' need for offsite. (Table 6). Market demand and the negative image are linked and so this is by far the greatest influence on the industry's ability to expand, a factor also found in other studies (Venables et al, 2004 and RGU, 2002).

A number of overseas firms that currently produce offsite components for their domestic market appear to be currently monitoring developments in the UK to identify a suitable time to enter the market (Venables et al, 2004). If the UK supply side cannot meet the increased demand for offsite then it may become economical for foreign firms to enter the UK market.

The three most significant advantages that UK suppliers thought foreign suppliers currently possessed over UK suppliers were cheaper labour, less regulation and cheaper materials (Figure 3), although less respondents thought that the foreign suppliers would still have these advantages in the near future (1 to 3 years), especially in the area of regulation.

The method used by the majority of suppliers (68\%) to overcome their clients' resistance to offsite was the provision of examples and case studies of previous successful uses of offsite. Other main methods included client 
experience and increased partnership and marketing (both over 50\%), all different ways of informing, educating and/or convincing the client of the possibilities and advantages of offsite. Reductions in price were only used by about a quarter of the suppliers in this survey, even though the increased expense of offsite was the main barrier to use quoted by clients/designers and contractors (Table 5). The majority of suppliers presumably sold the use of offsite on other factors such as speed of construction, quality and value rather than cost.

\section{Market share for offsite}

Many figures, percentages and values are frequently quoted for the value I size / proportion of the offsite industry in the UK. Samuelsson Brown et al (2003) quote the 'offsite fabrication' market to be worth $£ 800.9 \mathrm{~m}$ in 2002 and individual sectors within the offsite industry also produce their own figures, e.g. the British Precast Concrete Federation value their sector at $£ 1.8 \mathrm{bn}$ per annum (Clarke, 2003).

Many of these figures are frequently used and quoted however, without a full understanding of what the figures actually represent and how they are derived. This consequently leads to confusion and misrepresentation of the true value and size of the market. Misunderstandings are often made regarding both what qualifies as offsite, and what the value is.

A recent survey conducted by Loughborough University for Buildoffsite estimated the total value of the offsite market in the UK in 2004 to be $£ 2.2 \mathrm{bn}$ 
(Goodier and Gibb, 2005b). Table 7 shows the distribution across the different levels of offsite.

The value of the UK construction sector in the UK is shown in Table 8, divided up into new build, refurbishment and repair, and civil engineering. The total value of the UK construction sector in 2004 was $£ 106.8 \mathrm{bn}$ (Goodier and Gibb, 2005b). The proportion of the UK offsite market when compared with the total value of the UK construction sector, is estimated to be $2.1 \%$.

The true proportion of offsite which is imported or exported is extremely difficult, if not impossible, to obtain and/or calculate. The majority of the figures used to calculate these values are for the UK markets for the products, i.e. they include imports but exclude exports. It is well known that the UK imports a proportion of its offsite products, particularly in areas such as cladding. In addition, many one-off major projects, such as the Gateshead Bridge and Heathrow Terminal 5, use a significant proportion of offsite and these values are not always included in industry data. Parts of these structures will be included in some of the categories, but other parts will not.

\section{Medium-term growth forecast for offsite}

Figure 4 provides predictions of the growth of offsite between 2004 and 2009 (at 2004 prices). Nearly three quarters of the suppliers surveyed in the prOSPa survey thought that take-up of offsite by industry was increasing in their sector. This supports the findings of other research such as which predicted growth of $9.7 \%$ per annum (by value) by 2010 (Samuelsson Brown et al, 2003). The main reasons for this increase include increasing orders in 
key sectors for prefabricated buildings such as health and education, call centres, prisons, asylum centres and railways, the urgent need for additional key-workers accommodation and the lack of skilled construction personnel (AMA Research, 2002). The graph in Figure 4 shows a range of other assessments of the likely growth on the offsite market, ranging from hardly any growth to a virtual doubling of the market over the next five years. The slower, steady growth predicted by some reports suggests a gradual expansion of output amongst the manufacturers already in the market. This conservative view suggests a continued reliance on traditional methods with offsite being used in specialist applications. The more radical market projections would require new manufacturers to enter the market and thus, represents a target or aspiration rather than a realistic assessment based on the current market assessment outlined above.

\section{Location and certification}

The majority of the suppliers in the prOSPa survey were located in the NW and NE of England. The majority of the clients and designers however (62\%), used offsite the most in SE England. Reasons for this increased use in the SE included local availability, skills shortage, speed of delivery and labour costs. Many of the respondents however, thought that there was no regional difference in their use of offsite.

$77 \%$ of the suppliers in the prOSPa survey had obtained independent certification for some or all of their products and only $14 \%$ had not obtained any type of certification, with the main reasons being for market advantage and marketing reasons (both 68\%) and for insurance purposes (45\%). The 
house-buying public in the UK in particular have an attachment to both $\mathrm{NHBC}^{6}$ cover and to certification (RGU, 2002). Up to $69 \%$ of the suppliers questioned were also planning to obtain certification for more of their products in the near future, although one supplier commented that they would not be doing so if they could avoid it as obtaining certification was "very expensive and took an incredibly long time".

\section{Refurbishment}

All of the suppliers in this survey were involved in new build, with almost $60 \%$ of the respondents being involved in new build only. The remainder also supplied products for major refurbishment but only one supplier surveyed supplied products for maintenance.

When asked if the suppliers thought that there was a market for offsite in refurbishment in the UK, only about one third (35\%) said definitely yes. More than half of the suppliers surveyed were not sure if there was a market for this in the UK or not, possibly due to the sector waiting to see how the market develops before deciding what to do.

In recent years however, nearly half of all construction expenditure in the UK has been spent on refurbishment and repair compared with new construction (Goodier and Gibb, 2005b). Furthermore, in the house building sector this proportion rises to approximately two thirds (WBIMR, 1999). Refurbishment

\footnotetext{
${ }^{6}$ National House Building Council
} 
and repair is therefore a potentially large market for offsite in the UK into which it has already made some progress, but for which there is potential for significantly more. Not all of this market is suitable for the application of offsite however, as much of it is taken up by individual domestic improvements (i.e. DIY), but potential still exists.

\section{Labour and Skills}

The UK construction industry has a historically low level of training compared with other countries and it is estimated that between 70 and $80 \%$ of the workforce in construction in the UK has no formal qualifications (Dainty et al, 2004). A large proportion of the workforce are labourers, many of them selfemployed, and their skill-base is narrow and their training is limited. There is also an estimated annual turnover of between 65,000 and 75,000 people per annum (Dainty et al, 2003).

One of the reasons commonly quoted for using offsite is the lack, or excessive cost, of skilled labour, especially in London and SE England. Approximately three quarters of the respondents to the prOSPa survey from all sectors thought that all levels of offsite required either the same or less level of skill on site compared with traditional construction. A greater proportion of suppliers, perhaps predictably, thought that offsite required less skill on site than traditional construction.

It seemed that the higher the level of offsite (as defined in Table 2) then the stronger the respondents opinion as to whether the skill required was more or 
less (Table 9). For offsite levels 1 and 2 a large proportion of the respondents from all sectors thought that the level of skill required was the same, but for levels 3 and 4 the respondents seemed more polarised as to whether the skill required was more or less. More than a quarter of the contractors surveyed thought that offsite levels 3 and 4 required more skill compared with the equivalent product constructed traditionally, but more than four fifths of suppliers thought that offsite levels 3 and 4 required less skill compared with traditional construction.

More than $20 \%$ of the clients, designers and contractors in the prOSPa survey thought that insufficient worker skills were a barrier to the increased use of offsite (Table 5). Electricians, joiners and bricklayers were the three skills generally cited the most by all the sectors questioned as being in short supply and contributing to the increased demand for offsite products (Table 10). Contractors seem to be feeling the effects of the skills shortage the most as plumbers were the only trade which they felt was not increasing the demand for offsite to a significant degree. Conversely, the majority of suppliers thought that the lack of concreters, steel erectors and steel fixers contributed little to the increased demand for offsite.

It would seem at first that, with this general lack of skills, the UK construction industry would be perfectly placed for the increased use of offsite. Clarke (2002) argues however, that a skilled workforce is required to enable innovations such as offsite to be applied. Workers here in the UK are generally not provided with an initial broad-based training after which they 
specialise. Instead, they are usually trained for just one role which consequently makes adapting and multi-skilling difficult, which is what is required for an increased uptake in offsite. Suppliers are generally looking for semi-skilled and multi-skilled workers with a medium level of training, rather than specific trades (Venables et al, 2004). 89\% of offsite housing suppliers have also found that the core skills required in operatives to work in their plant did not exist in the general stock of labour from which they recruited and that they nearly always had to supply additional training (Venables et al, 2004). Appropriate skills availability was therefore also seen as a limitation for the increase in offsite as well as a driver.

More written responses were received to the prOSPa survey question of what steps could be taken to encourage people to enter careers in offsite than any other, with training and education, and raising the awareness of offsite being the two most commons responses. Additional replies mentioned that investment was needed in training and education at all levels, from school to university, the lack of, and need for, modern apprenticeship schemes, and the need for NVQ's in offsite and multi-skilling. Government training grants were suggested, both for offsite manufacturers and for training colleges, together with partnerships between local colleges and offsite suppliers . Raising the awareness of offsite, particularly to clients and the general public, was also mentioned by several respondents in order to relieve the technology of its poor historical 'pre-fab' image. Improved working environment and conditions for workers, both on site and in the offsite factory, consistency of employment, safety and improved wages for workers were also factors mentioned. 
Some of the contractor respondents suggested that the Government should encourage more clients (including itself) to use offsite products, therefore raising the demand for offsite. Others believe however, that the use of offsite should be left to market forces otherwise an artificial market for the product could be created.

\section{Information on offsite}

In the prOSPa survey, trade literature was found to be the most widely available type of information, for all sectors questioned, which could be expected as suppliers try to sell their products and inform customers of their services (Table 11).

Apart from trade literature and case studies however, the majority of respondents thought that all the other types of information on offsite were NOT already plentiful, particularly non-vested interest independent advice and costing on offsite. More than one third of the clients, designers and contractors in the prOSPa survey stated that honest comparative cost data of offsite versus traditional construction and comparative costs of different offsite systems would be the most useful information, if they could get it.

Clients, designers, contractors and other end users like to be fully informed of all the facts before they make strategic decisions and until information on offsite is freely and clearly available then the key decision makers will either 
think the offsite industry has hidden costs to hide or they will use a construction solution for which information is already plentiful and available.

\section{Future work}

If the aspiration growth targets of the Buildoffsite organisation are to be achieved, then the ability of market to cope, on both the supply and the demand sides, needs to be investigated.

For these targets to be met however, the negative past images of offsite need to be addressed and overcome and more transparent information is required for the decision makers in the construction process, particularly that relating to clear cost comparisons with traditional methods. Contradictions exist in that some practitioners believe that offsite is more expensive than traditional construction and a barrier to use, whilst a large proportion also think that one of the advantages of using offsite is a reduced initial and whole life cost. Further investigation is obviously required in this area in order for decision makers to make an informed decision.

\section{Conclusions}

The differing opinions of UK practitioners regarding the advantages and disadvantages of offsite vary widely, and this work has aimed to present and compare these views. Shorter onsite construction time and increased quality were seen as the major advantages and the (real or perceived) additional cost of offsite was the main barrier to its use.

The vast majority of respondents were aware of the possibilities and potential of offsite and the demand for offsite is clearly increasing, but it is not always 
clear in a project who is the main driver for its use. For the offsite market to continue to develop however, the negative connotations of offsite need to be overcome and more transparent information is required for the decision makers in the construction process, particularly that relating to clear cost comparisons with traditional methods.

Although the commonly-cited lack of skilled workers in the construction industry at first looks like an ideal opportunity for the increased use of offsite, offsite suppliers themselves are also suffering from a current lack of adequate semi-skilled and multi-skilled workers, which needs to be addressed and overcome if a significant expansion in the market is to occur.

The total value of the offsite market in the UK was estimated to be $£ 2.2 \mathrm{bn}$ in 2004 , or $2.1 \%$ of the total value of the UK construction sector, with nearly three quarters of suppliers thinking that take-up of offsite by industry is increasing. Assessments of the likely growth of the offsite market however, range from hardly any growth to a virtual doubling of the market over the next five years.

\section{Acknowledgements}

The authors wish to thank the financial support of the DTI, the assistance of the prOSPa partners BSRIA, CIRIA, Concrete Society, SCI and TRADA 
Technology, and the many people who took time completing the questionnaires for this report. 


\section{References}

AMA Research (2002) UK Prefabricated Buildings Market Report, AMA Research, Cheltenham, pp.100.

Barker, K. (2004) Review of Housing Supply, Securing our Future Housing Needs, London, The Stationery Office.

Barlow, J., Bartlett, K., Whitehead, C., and Hooper, A. (2002) Land for Housing: Current Practice and Future Options, York, Joseph Rowntree Land Enquiry.

Blismas, N.G., Pasquire, C.L. and Gibb, A.G.F. (2003) IMMPREST, Loughborough University, Loughborough, pp.150, ISBN 094797413 X.

Blismas, N., Pasquire, C. and Gibb, A.G.F (2006) Benefit Evaluation for Offsite Production in Construction, Construction Management and Economics, February 2006, 24, 121-130, ISBN 0144-6193.

Clarke, L., (2002) Standardisation and Skills: A Transnational Study of Skills, Education and Training for Prefabrication in Housing, London, University of Westminster Business School.

Clarke, M., (2003) British Precast - a Profile, Concrete, 37, Part 11, 6-7, The Concrete Society, London, ISSN 0010-5317.

Dainty, A.R.J., Ison, S.G. and Root, D.S. (2003) Bridging the Gap: East Midlands, CITB, Bircham Newton, UK.

Dainty, A.R.J., Ison, S.G. and Root, D.S. (2004) Bridging the Skills Gap: A Regionally Driven Strategy for Resolving the Construction Labour Market Crisis, Engineering, Construction and Architectural Management, 11, N0.4, 275-283, ISSN: 0969-9988.

Egan, J. (1998) Rethinking Construction, Report of the Construction Task Force, London, HMSO.

Gibb, A.G. (1999) Offsite Fabrication - Pre-assembly, Prefabrication and Modularisation, Whittles Publishing Services, London, pp.262, ISBN 1870325 $77 \times$.

Goodier, C.I. and Gibb, A.G.F. (2004) Barriers and Opportunities for Offsite Production, DTI, pp.75, ISBN: 1-873844-57-3.

Goodier, C.I. and Gibb, A.G.F. (2005a) The Offsite Market in the UK - a New Opportunity for Precast?, Borghoff, M., Gottschalg, A., and Mehl, R (eds.), Proceedings of the 18th BIBM International Congress and Exhibition, RAI Congress Centre, Amsterdam 11-14 May 2005, BFBN, Woerden, The Netherlands, 34-35, ISBN: 3-7625-3607-4. 
Goodier, C.I. and Gibb, A.G.F. (2005b) The Value of the UK Market for Offsite, BuildOffsite, pp.12, available from www.buildoffsite.com.

Harty, C., Goodier, C.I. and Soetanto, R. (2006) The Futures of Construction: A Review of Future Studies, accepted for publication in Construction Management and Economics, May 2006.

Pan, W., Gibb, A. G. F. and Dainty, A. R. J. (2006), Perspectives of UK housebuilders on the use of offsite modern methods of construction, Construction Management \& Economics, publication recommended / in press

RGU (2002) Overcoming Client and Market Resistance to Prefabrication and Standardisation in Housing, Robert Gordon University, Aberdeen, pp.400.

Samuelsson Brown, G. et al (2003) Offsite Fabrication - UK Attitudes and Potential, BSRIA, pp.130.

Soetanto, R., Goodier, C.I. and Harty, C. (2006) Synthesising Emerging Issues Within Key Futures Study Reports in Construction, accepted for publication in: Construction in the XXI century: Local and global challenges, Joint Int. Symp. of CIB Working Commissions W55, W65 and W86, Rome, 1820 Oct. 2006, .

Venables, T., et al. (2004) Manufacturing Excellence - UK Offsite Capacity, Innovation Studies Centre, Imperial College, London, pp.62.

Worldwide Business Information and Market Reports, WBIMR (1999) KN45029 Key Note Construction Industry (UK), ISBN 1-84168-014-1. 


\section{TABLES}

\begin{tabular}{|l|c|}
\hline Organisation type & $\begin{array}{c}\text { \% of } \\
\text { respondents }\end{array}$ \\
\hline Client / end user & 27 \\
Specialist supplier & 24 \\
Other & 24 \\
Main contractor & 19 \\
Architect / Designer & 13 \\
Specialist consultant / designer & 12 \\
Project / Construction Managers & 8 \\
M\&E consultant / designer & 4 \\
Maintenance contractor / FM & 1 \\
\hline
\end{tabular}

Table 1. Type of organisation.

Note: 'Other' included multi-discipline consultants and specialist subcontractors.

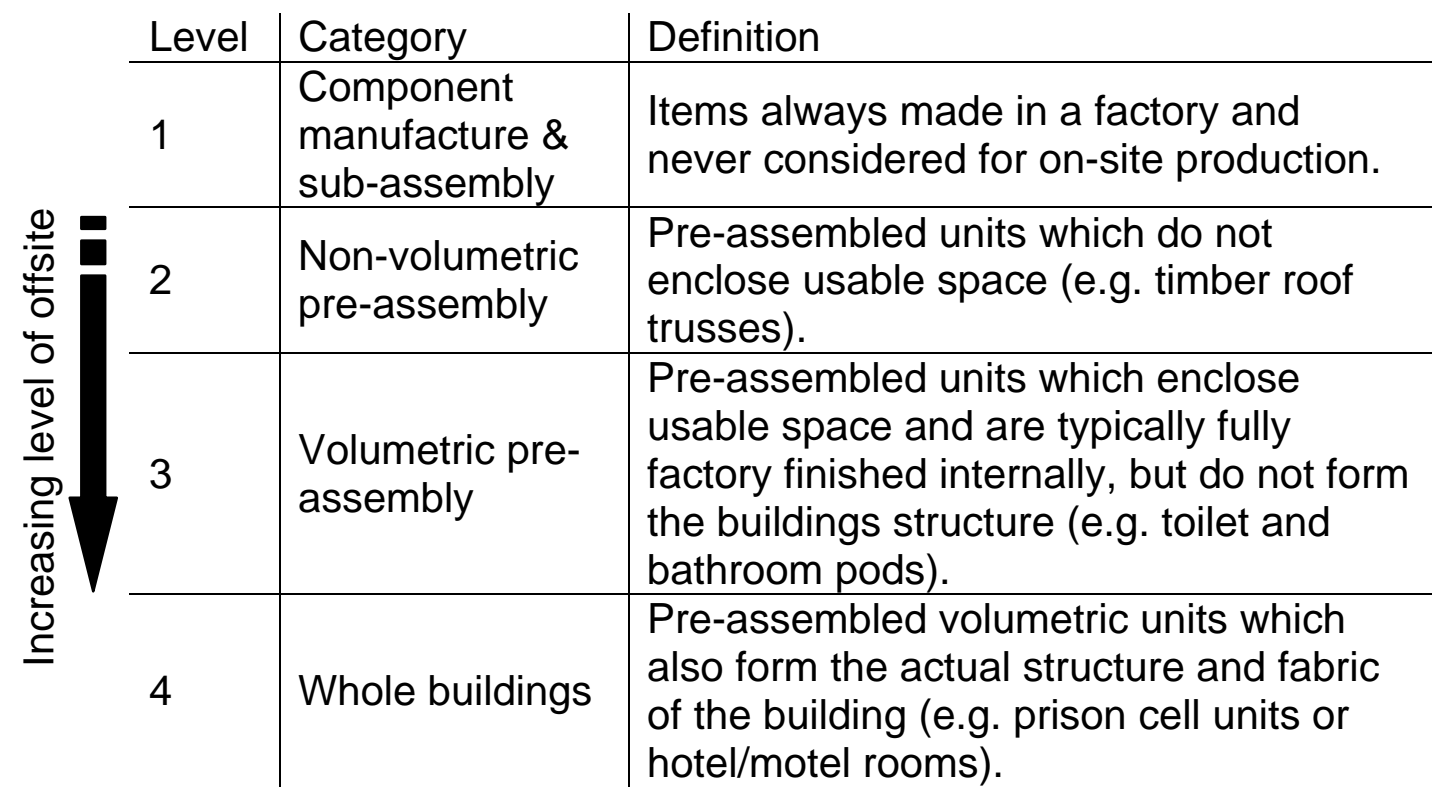

Table 2. Levels of offsite (adapted from Gibb, 1999). 


\begin{tabular}{|l|c|c|c|}
\hline \multirow{2}{*}{ Area of Work } & \multicolumn{3}{|c|}{ \% of respondents } \\
\cline { 2 - 4 } & $\begin{array}{c}\text { Clients / } \\
\text { designers }\end{array}$ & Suppliers & Contractors \\
\hline Public/social housing & 51 & 39 & 46 \\
Private housing & 33 & 52 & 46 \\
Offices & 33 & 39 & 46 \\
Hospitals/health & 31 & 52 & 69 \\
Other & 26 & 13 & 23 \\
Retail & 26 & 26 & 23 \\
Schools & 26 & 35 & 69 \\
University/research & 23 & 4 & 15 \\
Student accommodation & 21 & 39 & 23 \\
Factories/warehousing & 21 & 17 & 85 \\
Other Public (incl. Defence) & 18 & 17 & 15 \\
Hotels/leisure & 18 & 52 & 23 \\
Restaurants/Fast food & 8 & 4 & 8 \\
Supermarkets & 5 & 13 & 31 \\
Defence accommodation & 8 & 30 & 31 \\
Other offsite producers & 0 & 17 & 0 \\
\hline
\end{tabular}

Table 3. Main areas of work within the UK construction market.

Note: 'Other' includes prisons, water, transportation, air and rail.

\begin{tabular}{|l|cc|cc|}
\hline \multirow{2}{*}{ Advantages } & \multicolumn{2}{|c|}{ Clients / designers } & \multicolumn{2}{c|}{ Contractors } \\
\cline { 2 - 5 } & $\begin{array}{c}\% \text { of } \\
\text { respondents }\end{array}$ & $\begin{array}{c}\text { as } 1^{\text {st }} \\
\text { choice }\end{array}$ & $\begin{array}{c}\text { \% of } \\
\text { respondents }\end{array}$ & $\begin{array}{c}\% \text { as } 1^{\text {st }} \\
\text { choice }\end{array}$ \\
\hline Decreased construction time & 87 & 38 & 92 & 69 \\
Increased quality & 79 & 28 & 77 & 15 \\
More consistent product & 77 & 18 & 54 & 0 \\
Reduced snagging \& defects & 79 & 8 & 69 & 0 \\
Increased value & 51 & 5 & 23 & 0 \\
Increased sustainability & 49 & 3 & 31 & 0 \\
Reduced initial cost & 44 & 3 & 15 & 8 \\
Reduced whole life cost & 41 & 0 & 15 & 0 \\
Increased flexibility & 33 & 0 & 15 & 0 \\
Greater customisation options & 33 & 3 & 0 & 0 \\
Increased component life & 28 & 0 & 15 & 0 \\
Other & 18 & 15 & 8 & 8 \\
\hline
\end{tabular}

Table 4. Advantages of offsite.

Note: 'Other' includes improved health and safety and reduced requirement for skilled labour. 


\begin{tabular}{|c|c|c|c|c|}
\hline \multirow[b]{2}{*}{ Barriers } & \multicolumn{2}{|c|}{ Clients / designers } & \multicolumn{2}{|c|}{ Contractors } \\
\hline & $\begin{array}{c}\% \text { of } \\
\text { respondents }\end{array}$ & $\begin{array}{l}\% \text { as } 1^{\text {st }} \\
\text { choice }\end{array}$ & $\begin{array}{c}\% \text { of } \\
\text { respondents }\end{array}$ & $\begin{array}{c}\% \text { as } 1^{\mathrm{st}} \\
\text { choice }\end{array}$ \\
\hline More expensive & 67 & 54 & 77 & 38 \\
\hline Longer lead-in times & 46 & 8 & 62 & 8 \\
\hline Client resistance & 38 & 13 & 31 & 23 \\
\hline Lack of guidance \& info & 33 & 5 & 46 & 0 \\
\hline Increased risk & 36 & 0 & 15 & 0 \\
\hline Few codes/standards available & 33 & 3 & 23 & 0 \\
\hline Other & 31 & 18 & 15 & 8 \\
\hline Negative image & 28 & 0 & 46 & 8 \\
\hline Not locally available & 18 & 5 & 15 & 0 \\
\hline No personal experience of use & 18 & 3 & 38 & 15 \\
\hline Obtaining finance & 18 & 3 & 8 & 0 \\
\hline Insufficient worker skills & 21 & 0 & 23 & 0 \\
\hline Reduced quality & 13 & 0 & 15 & 0 \\
\hline Restrictive regulations & 13 & 0 & 31 & 0 \\
\hline
\end{tabular}

Table 5. Main barriers hindering the increased use of offsite.

\begin{tabular}{|l|c|}
\hline Limiting factors & $\begin{array}{c}\% \text { of } \\
\text { respondents }\end{array}$ \\
\hline Negative image of offsite & 65 \\
Excessive competition & 50 \\
Manufacturing capacity & 48 \\
Market demand & 36 \\
Inadequate worker skills & 32 \\
Restrictive regulations & 32 \\
Obtaining finance & 32 \\
Technical limitations & 30 \\
\hline
\end{tabular}

Table 6. Factors limiting suppliers ability to expand.

\begin{tabular}{|c|l|c|}
\hline Level of offsite & Description & Value (£bn) \\
\hline 4 & Modular and portable buildings & 0.64 \\
3 & Volumetric pre-assembly & 0.29 \\
2 & Non-volumetric pre-assembly & 1.28 \\
\hline & Total offsite & 2.2 \\
\hline
\end{tabular}

Table 7. Value of the Offsite market in the UK in 2004 (Goodier and Gibb, 2005b). 


\begin{tabular}{|l|c|c|}
\hline UK construction sector & Value (£bn) & \% offsite \\
\hline New build (ex civil) & 53.3 & 4.1 \\
New civil engineering construction & 8.5 & \\
\hline Total new build (inc. civil) & 61.8 & 3.6 \\
\hline & & \\
\hline Construction refurbishment and repair & 45.0 & \\
\hline Total UK construction (new, refurb \& civil) & 106.8 & 2.1 \\
\hline
\end{tabular}

Table 8. Value of the construction sector in the UK and \% Offsite in 2004 (Goodier and Gibb, 2005b).

\begin{tabular}{|l|c|ccc|}
\hline \multirow{2}{*}{ Sector } & Level of & \multicolumn{3}{|c|}{ \% of respondents who replied } \\
\cline { 3 - 5 } & offsite & Less & Same & More \\
\hline \multirow{4}{*}{ Client / designer } & 1 & 42 & 42 & 17 \\
& 2 & 50 & 42 & 8 \\
& 3 & 64 & 25 & 11 \\
& 4 & 67 & 8 & 25 \\
\hline \multirow{5}{*}{ Contractor } & 1 & 23 & 77 & 0 \\
& 2 & 18 & 64 & 18 \\
& 3 & 64 & 9 & 27 \\
Supplier & 4 & 55 & 18 & 27 \\
& 1 & 33 & 47 & 20 \\
& 2 & 56 & 25 & 19 \\
& 3 & 86 & 7 & 7 \\
& 4 & 81 & 6 & 13 \\
\hline
\end{tabular}

Table 9. Skill level required by offsite on site compared with equivalent product constructed traditionally (by level).

\begin{tabular}{|l|ccc|}
\hline \multirow{2}{*}{ Skill } & \multicolumn{3}{|c|}{ \% of respondents } \\
\cline { 2 - 4 } & Client / designer & Supplier & Contractors \\
\hline Electricians & 65 & 38 & 67 \\
Joiners & 59 & 76 & 83 \\
Bricklayers & 44 & 71 & 58 \\
Steel-fixers & 35 & 19 & 42 \\
Steel-erectors & 32 & 10 & 33 \\
Other & 29 & 48 & 42 \\
Concreters & 26 & 10 & 50 \\
Plumbers & 12 & 33 & 8 \\
\hline
\end{tabular}

Table 10. Skill shortages contributing to the increased demand for offsite. 


\begin{tabular}{|l|c|c|c|}
\hline \multirow{2}{*}{ Type of information } & \multicolumn{3}{|c|}{ \% of respondents } \\
\cline { 2 - 4 } & $\begin{array}{c}\text { Client / } \\
\text { designer }\end{array}$ & Supplier & Contractor \\
\hline Trade literature & 61 & 52 & 67 \\
Successful case studies / best practice & 58 & 43 & 42 \\
Technical manuals/designs & 39 & 38 & 33 \\
General web resources & 28 & 29 & 42 \\
Technical research reports & 22 & 24 & 33 \\
Cost data & 11 & 10 & 17 \\
Other & 6 & 14 & 25 \\
\hline
\end{tabular}

Table 11. Types of information on offsite already plentiful. 


\section{FIGURES}

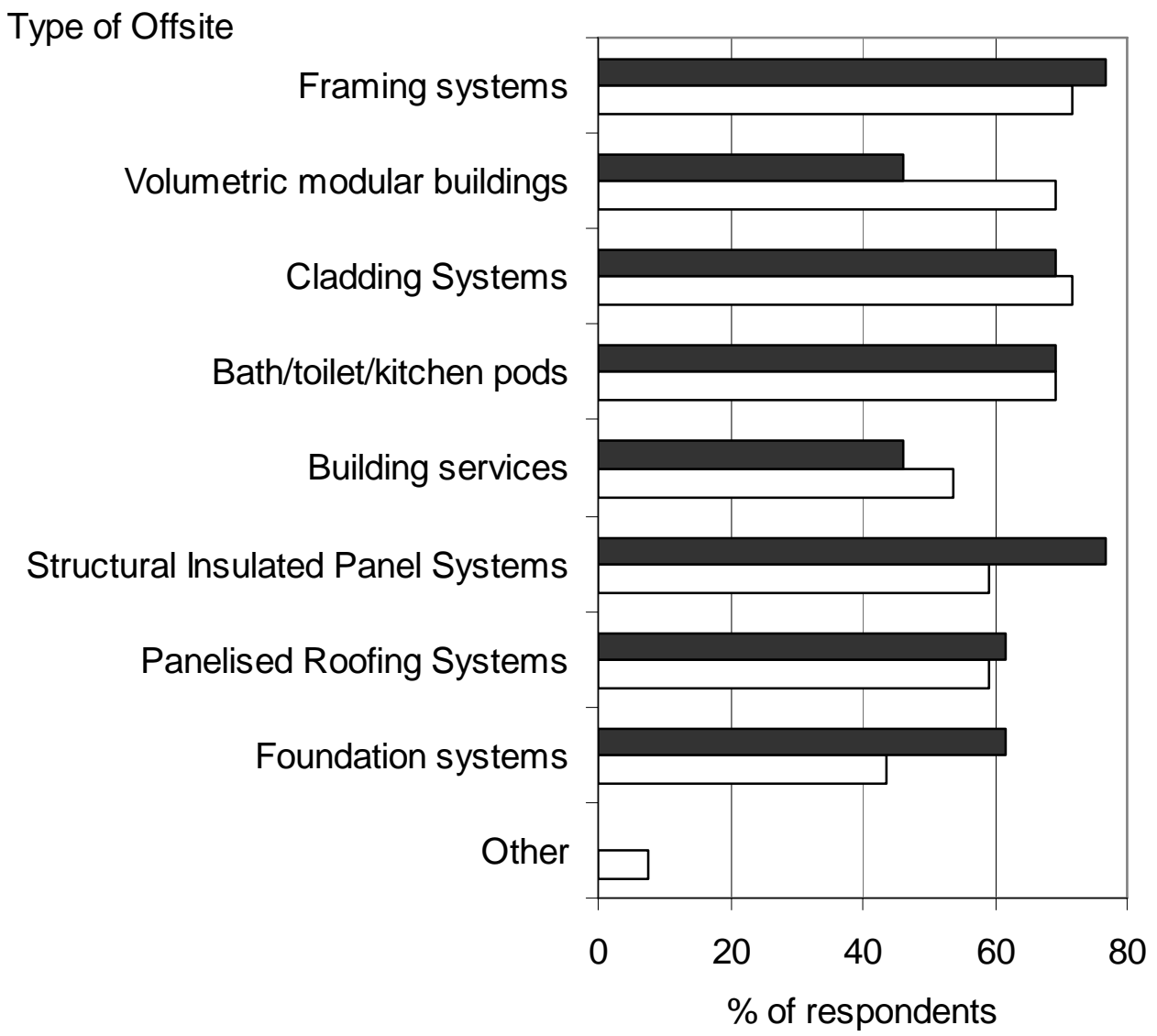

Figure 1. Type of Offsite most commonly used for projects.

- Contractors

$\square$ Client / designer 


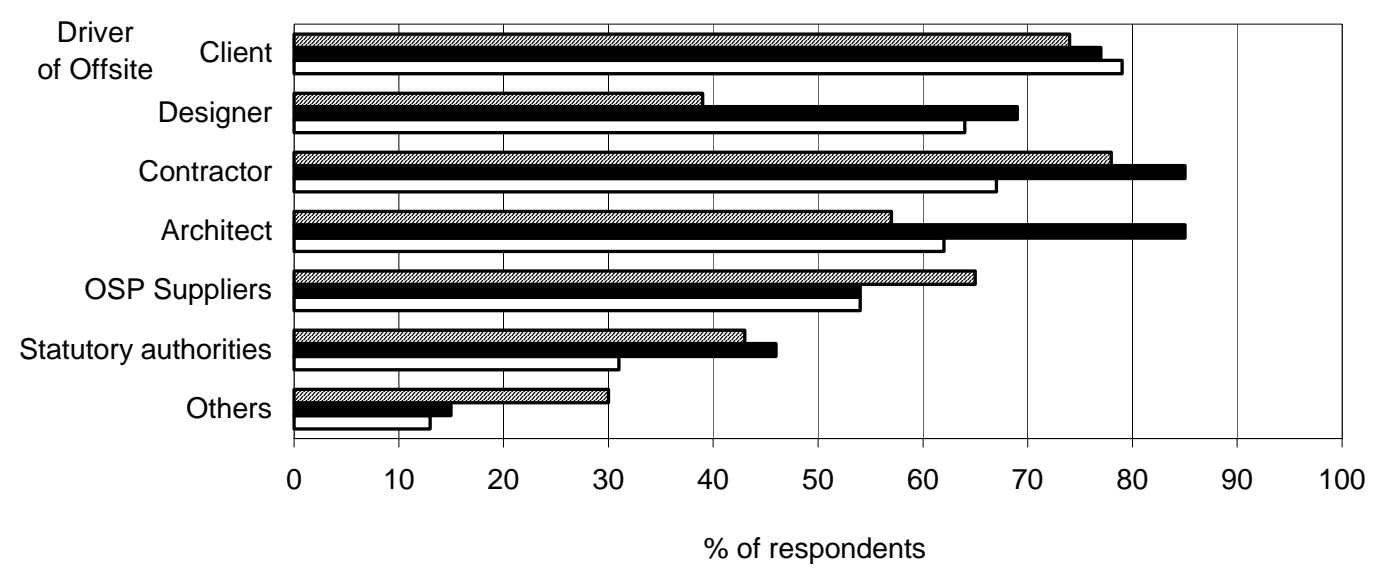

Figure 2. Main driver of offsite on a project.

$\square$ Suppliers

- Contractors

$\square$ Client / designer

'Others' included the Government and the Housing Corporation

Advantages

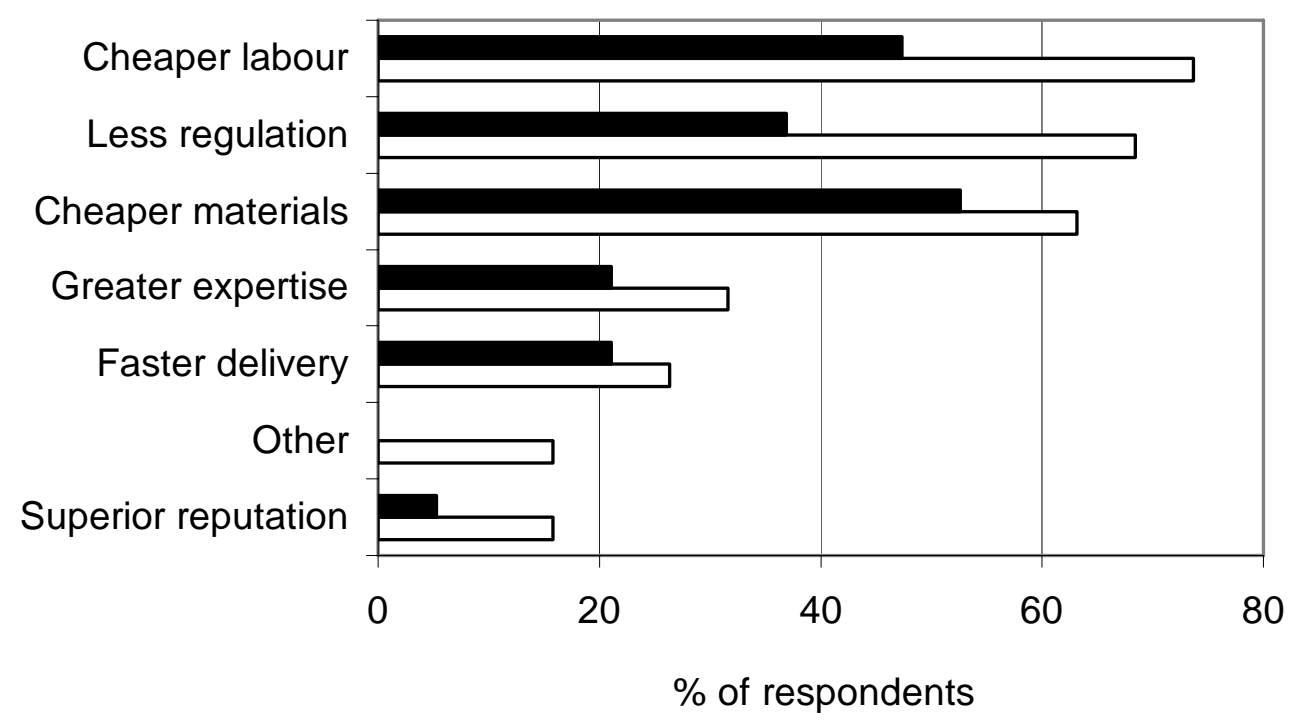

Figure 3. Advantages of foreign suppliers/importers compared with UK suppliers.

- Near future (1 to 3 years)

$\square$ Currently

'Other' included greater expertise, faster delivery and superior reputation. 


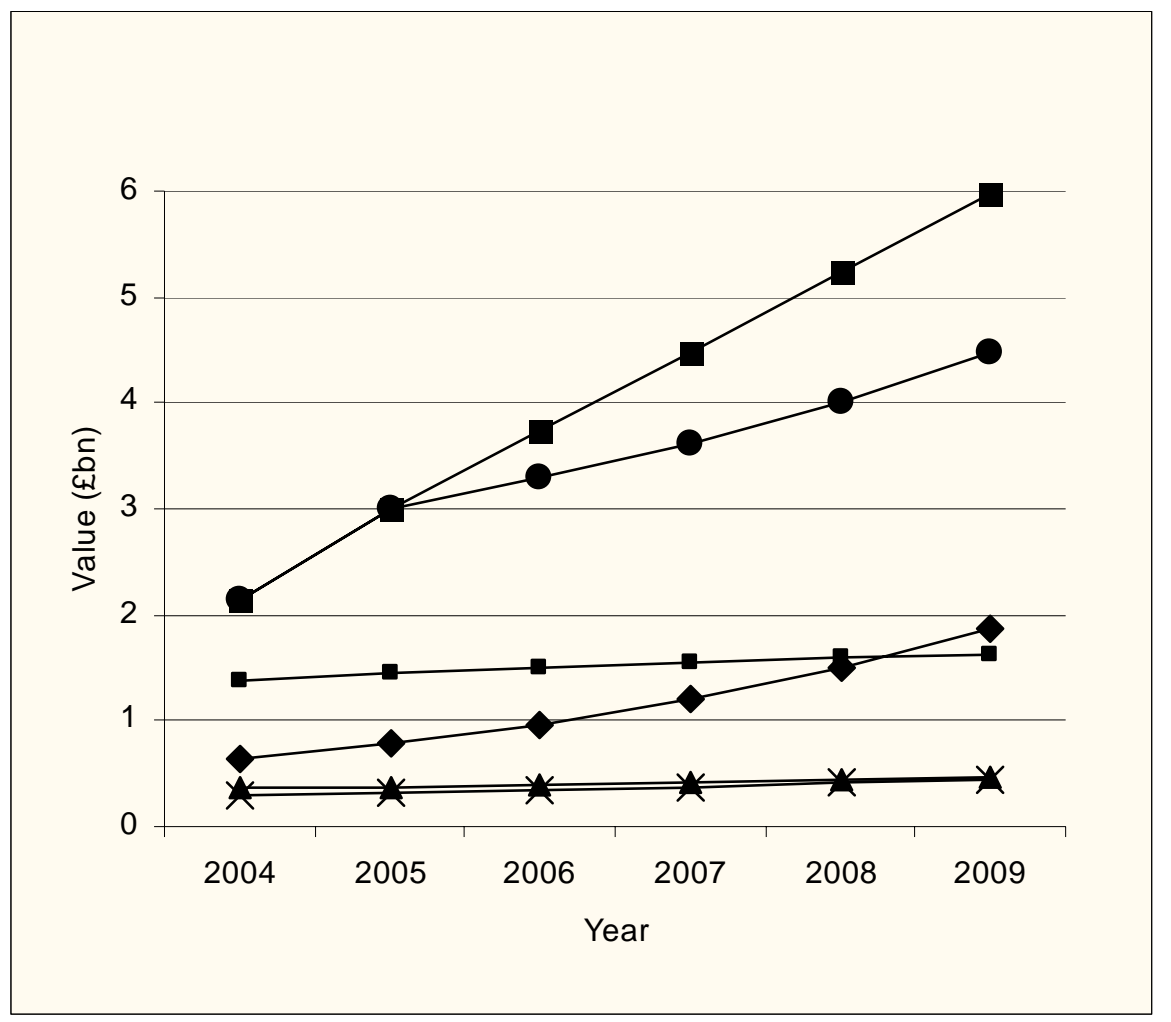

Figure 4. Comparison of market growth projections and targets for offsite applications

- Buildoffsite aspirational target

- Loughborough University estimated total offsite market

- MSi Modular building prediction (on\&off site)

- Mintel cladding prediction (total)

- Mintel precast prediction (ex cladding)

$*$ BSRIA M\&E prediction (ex Modular)

[Editor's Note to artist re-drawing Figures: Please ensure font in Figure 4 is Times Roman, and the correct size. Also, please omit the background colour, the external border and the grid lines.] 